\title{
ДОСЛІДЖЕННЯ АВТОНОМНОЇ РЕГУЛЯЦІЇ СЕРЦЕВОГО РИТМУ МОЛОДИХ ЩУРІВ ПРИ ПОЄДНАНОМУ ВПЛИВІ ГІПОКСИЧНОЇ АТМОСФЕРИ Й МЕЛАТОНІНУ
}

\author{
ДВНЗ «Тернопільський державний медичний університет \\ імені І. Я. Горбачевського МОЗ України»
}

\begin{abstract}
Поєднання низки несприятливих чинників, таких як гіпоксичний ефект атмосфери, розумова праця й емоційний стрес, створює передумови для розвитку дезадаптивних змін у регуляторних системах організму. Вивчали зміни автономної регуляції серцевого циклу щурів при поєднаному впливі гіпоксичної атмосфери й мелатоніну. Метою дослідження було виявити участь мелатоніну як чинника синхронізації біоритмів у впливі на автономну регуляцію серцевого ритму в молодих і дорослих щурів при інкубації в гіпоксичному середовищі за умов зниженого атмосферного тиску. Застосування препаратів мелатоніну у терапевтичних дозах у дорослих осіб, після завершення процесу статевого дозрівання, може бути корисним для профілактики метеотропних реакцій і покращення працездатності організму за несприятливих умов III типу погоди.
\end{abstract}

Ключові слова: гіпоксичний ефект, серцевий цикл, варіаційна пульсометрія, знижений атмосферний тиск.

\section{ИССЛЕДОВАНИЕ АВТОНОМНОЙ РЕГУЛЯЦИИ СЕРДЕЧНОГО РИТМА МОЛОДЫХ КРЫС ПРИ СОВМЕСТНОМ ВОЗДЕЙСТВИИ ГИПОКСИЧЕСКОЙ АТМОСФЕРЫ И МЕЛАТОНИНА}

Н. М. Волкова

ГВУЗ «Тернопольский государственный медицинский университет имени И. Я. Горбачевского МЗ Украины»

\begin{abstract}
Сочетание ряда неблагоприятных факторов, таких как гипоксический эффект атмосферы, умственный труд и эмоциональный стресс, создает предпосылки для развития дезадаптивных изменений в регуляторных системах организма. Изучали изменения автономной регуляции сердечного цикла крыс при совместном воздействии гипоксической атмосферы и мелатонина. Целью исследования было выявить участие мелатонина, как фактора синхронизации биоритмов в воздействии на автономную регуляцию сердечного ритма у молодых и взрослых крыс при инкубации в гипоксической среде в условиях сниженного атмосферного давления. Применение препаратов мелатонина в терапевтических дозах у взрослых, после завершения процесса полового созревания, может быть полезным для профилактики метеотропных реакций и улучшения работоспособности организма при неблагоприятных условиях III типа погоды.
\end{abstract}

Ключевые слова: гипоксический эффект, сердечный цикл, вариационная пульсометрия, сниженное атмосферное давление.

\section{RESEARCH OF AUTONOMOUS REGULATION OF HEART RATE IN YOUNG RATS AT COMBINED INFLUENCE OF HYPOXIC ATMOSPHERE AND MELATONIN}

N. M. Volkova

\author{
SHEI «Ternopil State Medical University by I. Ya. Horbachevsky of MPH of Ukraine»
}

\begin{abstract}
The combination of a number of adverse factors as the effect of hypoxic atmosphere, mental work and emotional stress, creates conditions for the development of maladaptive changes in the regulatory systems of the body. changes in autonomic regulation of cardiac cycle of rats under hypoxic atmosphere combined influence and melatonin were studied. The aim of the study was to identify the role of melatonin as factor of biorhythms synchronization in the impact on autonomous regulation of heart rate in young and adult rats with hypoxic incubation environment under conditions of low atmospheric pressure.

(C) Н. М. Волкова
\end{abstract}


The use of melatonin drug in therapeutic doses in adults, after the completion of puberty, may be useful for the prevention of meteotropic reactions and improve the efficiency of the organism in adverse weather conditions, type III.

Key words: hypoxic effects, cardiac cycle variation pulsometry, low atmospheric pressure.

Зниження атмосферного тиску при III типі погоди створює гіпоксичний ефект атмосфери [1], який викликає в організмі людини суттєві зміни центральної регуляції автономних функцій. Поєднання низки несприятливих чинників, таких як гіпоксичний ефект атмосфери, розумова праця й емоційний стрес, створює передумови для розвитку дезадаптивних змін у регуляторних системах організму. Наслідками геоекологічного стресу $є$ порушення функції вісцеральних гомеостатичних систем, зниження адаптаційних резервів організму [2].

3 літератури відомо про ефекти введення мелатоніну за півгодини до початку гіпоксичного впливу, що зменшувало інтенсивність ліпопероксидації у тканині мозку [3, 4], підвищувало антиоксидантну активність ферментів у базальних ядрах головного мозку $[5,6]$. У сучасних літературних джерелах обговорюється здатність мелатоніну до нормалізації артеріального тиску, покращення трофіки міокарда [7], але обмаль даних про можливість застосування мелатоніну для профілактики метеотропних реакцій. Дане питання можна вивчити за допомогою моделювання гіпоксичного ефекту атмосфери в експерименті.

Мета дослідження. Виявити участь мелатоніну, як чинника синхронізації біоритмів, у впливі на автономну регуляцію серцевого ритму в молодих і дорослих щурів при інкубації в гіпоксичному середовищі за умов зниженого атмосферного тиску.

Матеріали і методи дослідження. Вивчали зміни автономної регуляції серцевого циклу щурів при поєднаному впливі гіпоксичної атмосфери й мелатоніну. Експериментальні дослідження проведені на нелінійних молодих щурах обох статей віком 1-1,5 місяці масою 70-100 г. Усі експерименти проведені при метеоситуації I типу, що виключало несприятливий вплив природних змін атмосферних умов. В експериментальній групі (10 щурів) реєстрували кардіоінтервалограму інтактної тварини й після внутрішньоочеревинного введення розчину мелатоніну в дозі 1 мг/кг. Через 0,5 год. тварину поміщали у гіпоксичне середовище на 1 год. із наступною реєстрацією кардіоінтервалограми. Тварини контрольної групи (10 щурів) отримували гіпоксичний вплив без введення мелатоніну. Вплив гіпоксичної атмосфери створювали за допомогою зниження тиску на 50,76 гПа (0,05 атм) в апараті Комовського й утримування занаркотизованого щура під скляним дзвоном. При аналізі результатів кардіоінтервалогафії обраховували середнє значення, стандартне відхилення, варіаційний розкид (AX), моду (Мо), амплітуду моди (AМо), індекс напруження (IH), вегетативний показник ритму (ВПР).

Усіх тварин утримували на стандартному раціоні віварію. Дослідження виконували відповідно до «Загальних етичних принципів експериментів на тваринах», ухвалених Першим національним конгресом 3 біоетики (Київ, 2001) та узгоджених 3 положеннями «Європейської конвенції щодо захисту хребетних тварин, які використовуються для експериментальних і інших наукових цілей» (Страсбург, 1986). Експерименти були дозволені комісією з біоетики ДВНЗ «Тернопільський державний медичний університет імені І. Я. Горбачевского МО3 України».

Результати та їх обговорення. Дослідження поєднаного впливу мелатоніну і модельованої гіпоксії показало такі особливості автономного контролю серцевого ритму. У контрольній групі у молодих тварин гіпоксія спричиняла суттєве зменшення IH і ВПР (табл. 1).

У дорослих тварин контрольної групи після гіпоксичного впливу суттєво зростав тонус парасимпатичної нервової системи, за зменшенням IH і зростанням тривалості кардіоциклу (табл. 2). 3 літератури відомо, що у молодих щурів фізіологічно вище виділення мелатоніну, ніж у дорослих особин, що має значення в регуляції процесу статевого дозрівання [8]. У контрольній групі молодих щурів гіпоксичний вплив спричинив зниження IH на $42 \%$ і ВПР - на $40 \%$, а у дорослих особин за аналогічних умов ІН зменшився на $87 \%$ і ВПР - на $80 \%$. Отже, у молодих щурів активніше працюють регуляторні механізми, які забезпечують інтенсивнішу роботу серця за умов гіпоксії, порівняно 3 дорослими щурами.

У молодих тварин експериментальної групи введення мелатоніну через 30 хв спричиняло зростання середньої тривалості кардіоциклу і зменшення ВПР і ІН. Поєднаний вплив мелатоніну і гіпоксії спричинив значно інтенсивнішу парасимпатикото- 


\section{МЕДИЧНА ІНФОРМАТИКА TA IHЖЕНЕРІЯ}

нію, ніж у молодих тварин контрольної групи після утримання у гіпоксичному середовищі. Водночас, порівняно $з$ інтактним станом, після поєднаного впливу мелатоніну і гіпоксії у молодих щурів IH знижувався на 88 \% і ВПР - на 80 \%. Отже, додаткове введення мелатоніну перед гіпоксичним впливом у молодих щурів пригнічувало активність центрального контуру автономної регуляції серцевого ритму.

Введення мелатоніну дорослим тваринам експериментальної групи викликало через 30 хв активацію парасимпатичних впливів на серцевий ритм (табл. 2).

Таблиця 1. Стан автономної регуляції молодих тварин при впливі гіпоксії і мелатоніну

\begin{tabular}{|c|c|c|c|c|c|}
\hline \multirow{2}{*}{ Показник } & & \multicolumn{4}{|c|}{ Група тварин } \\
\hline & & \multirow{2}{*}{$\begin{array}{c}\text { інтактні } \\
0,141 \pm 0,001\end{array}$} & \multirow{2}{*}{$\begin{array}{c}\begin{array}{c}\text { після гіпоксії } \\
\text { без мелатоніну }\end{array} \\
0,195 \pm 0,008\end{array}$} & \multirow{2}{*}{$\begin{array}{c}\text { після введення } \\
\text { мелатоніну } \\
-\end{array}$} & \multirow{2}{*}{$\begin{array}{c}\text { після гіпоксії на фоні } \\
\text { введення мелатоніну } \\
-\end{array}$} \\
\hline$M$ & $\mathrm{~K}$ & & & & \\
\hline $\mathrm{IV}, \mathrm{C}$ & $\mathrm{e}$ & $0,162 \pm 0,001$ & - & $0,210 \pm 0,001$ • & $0,289 \pm 0,014$ *\# \\
\hline \multirow{2}{*}{$\Delta \mathrm{X}, \mathrm{c}$} & K & $0,004 \pm 0,001$ & $0,005 \pm 0,001$ & - & - \\
\hline & $\mathrm{e}$ & $0,004 \pm 0,001$ & - & $0,005 \pm 0,001$ & $0,070 \pm 0,026 * \#$ \\
\hline \multirow{2}{*}{ Mo, c } & $\mathrm{K}$ & $0,142 \pm 0,001$ & $0,195 \pm 0,008$ & - & - \\
\hline & $\mathrm{e}$ & $0,162 \pm 0,001$ & - & $0,210 \pm 0,001$ • & $0,282 \pm 0,013 * \#$ \\
\hline \multirow{2}{*}{ AMo, $\%$} & $\mathrm{~K}$ & $33,600 \pm 3,777$ & $32,900 \pm 3,695$ & - & - \\
\hline & $\mathrm{e}$ & $41,650 \pm 0,935$ & - & $41,300 \pm 1,467$ & $18,550 \pm 2,071$ ॥\# \\
\hline \multirow{2}{*}{ IH, ум. од. } & $\mathrm{K}$ & $27599,132 \pm 323,706$ & $16131,464 \pm 72,401$ & - & - \\
\hline & $\mathrm{e}$ & $31079,670 \pm 79,885$ & - & $22149,19 \pm 12,976$ & $3430,6 \pm 25,064 * \#$ \\
\hline \multirow{2}{*}{ ВПР, ум. од. } & $\mathrm{K}$ & $1652,811 \pm 27,655$ & $977,675 \pm 9,483$ & - & - \\
\hline & $\mathrm{e}$ & $1482,588 \pm 87,731$ & - & $1066,148 \pm 46,264$ & $297,238 \pm 6,557$ ॥ \\
\hline \multicolumn{6}{|c|}{$\begin{array}{l}\text { Примітки: } \\
\text { 1. - }<0,05 \text { порівняно з інтактними тваринами; } \\
\text { 2. * - }<0,05 \text { порівняно з ефектом введення мелатоніну; } \\
\text { 3. \# - р<0,05 порівняно з контрольною групою; } \\
\text { 4. к - контрольна група тварин, які не піддавалися гіпоксії; } \\
\text { 5. е - експериментальна група тварин, які отримали гіпоксичний вплив. }\end{array}$} \\
\hline
\end{tabular}

Таблиця 2. Стан автономної регуляції дорослих тварин при впливі гіпоксії і мелатоніну

\begin{tabular}{|c|c|c|c|c|c|}
\hline \multirow{2}{*}{\multicolumn{2}{|c|}{ Показник }} & \multicolumn{4}{|c|}{ Група тварин } \\
\hline & & \multirow{2}{*}{$\begin{array}{c}\text { інтактні } \\
0,165 \pm 0,002\end{array}$} & \multirow{2}{*}{$\begin{array}{c}\begin{array}{c}\text { після гіпоксії } \\
\text { без мелатоніну }\end{array} \\
0,217 \pm 0,014 \\
\end{array}$} & \multirow{2}{*}{$\begin{array}{c}\text { після введення } \\
\text { мелатоніну } \\
-\end{array}$} & \multirow{2}{*}{$\begin{array}{c}\begin{array}{c}\text { після гіпоксії на фоні } \\
\text { введення мелатоніну }\end{array} \\
- \\
\end{array}$} \\
\hline \multirow{2}{*}{ M, c } & $\mathrm{K}$ & & & & \\
\hline & $\mathrm{e}$ & $0,165 \pm 0,001$ & - & $0,197 \pm 0,002$ & $0,202 \pm 0,002$ ॥ \\
\hline \multirow{2}{*}{$\Delta \mathrm{X}, \mathrm{c}$} & $\mathrm{K}$ & $0,009 \pm 0,001$ & $0,006 \pm 0,042$ & - & - \\
\hline & $\mathrm{e}$ & $0,008 \pm 0,001$ & - & $0,025 \pm 0,001 \star$ & $0,023 \pm 0,009 \star^{*}$ \\
\hline \multirow{2}{*}{ Mo, c } & $\mathrm{K}$ & $0,163 \pm 0,002$ & $0,208 \pm 0,008$ & - & - \\
\hline & $\mathrm{e}$ & $0,165 \pm 0,001$ & - & $0,197 \pm 0,002$ & $0,202 \pm 0,002$ * \\
\hline \multirow{2}{*}{ AMo, $\%$} & $\mathrm{~K}$ & $40,0 \pm 1,0$ & $16,0 \pm 8,0$ & - & - \\
\hline & $\mathrm{e}$ & $48,950 \pm 1,776$ & - & $26,400 \pm 1,398$ & $28,300 \pm 1,183 \#$ \\
\hline \multirow{2}{*}{ IH, ум. од. } & $\mathrm{K}$ & $13780,42 \pm 116,79$ & $1757,4 \pm 75,88 \bullet \nabla$ & - & - \\
\hline & $\mathrm{e}$ & $18227,273 \pm 31,332$ & - & $2877,452 \pm 77,361$ • & $8297,613 \pm 185,885$ *\# \\
\hline \multirow{2}{*}{ ВПР, ум. од. } & $\mathrm{K}$ & $681,361 \pm 41,163$ & $161,583 \pm 16,194 \boldsymbol{\nabla}$ & - & - \\
\hline & $\mathrm{e}$ & $1108,552 \pm 32,451$ & - & $214,526 \pm 15,664$ & $558,111 \pm 65,141 \star * \#$ \\
\hline \multicolumn{6}{|c|}{$\begin{array}{l}\text { Примітки: } \\
\text { 1. - }<00,05 \text { порівняно з інтактними тваринами; } \\
\text { 2. *-р<0,05 порівняно з ефектом введення мелатоніну; } \\
\text { 3. \#-р }<0,05 \text { порівняно з контрольною групою; } \\
\text { 4. } \mathbf{\nabla}-\text { p }<0,05 \text { порівняно з молодими щурами; } \\
\text { 5. к - контрольна група тварин, які не піддавалися гіпоксії; } \\
\text { 6. е - експериментальна група тварин, які отримали гіпокск }\end{array}$} \\
\hline
\end{tabular}


В експериментальній групі дорослих тварин поєднаний вплив мелатоніну і гіпоксії спричинив суттєво більшу активацію центрального контуру регуляції серцевого ритму, порівняно із тваринами контрольної групи, які отримали тільки гіпоксичний вплив. У дорослих щурів експериментальної групи ступінь зниження IН після поєднаного впливу мелатоніну і гіпоксії склав $54 \%$ від результату в інтактному стані, а зниження ВПР - $50 \%$.

Отримані нами результати показують, що вплив мелатоніну перед гіпоксією, яка моделює умови III типу погоди, спричиняє оптимізацію механізмів автономного контролю серцевого ритму. На нашу думку, застосування препаратів мелатоніну у терапевтичних дозах у дорослих осіб, після завершення процесу статевого дозрівання, може бути корисним для профілактики метеотропних реакцій і покращення працездатності організму за несприятливих умов III типу погоди.

Дані про роль мелатоніну в організмі дозволили суттєво уточнити інтерпретацію наших результатів. Цікаво занотувати відомості літератури про пряму кореляцію рівня мелатоніну до шкільної

\section{Література}

1. Ермакова Л. Н. Влияние метеорологических условий на самочувствие человека / Л. Н. Ермакова, Е. С. Ермакова // Географический вестник. - 2012. - № 2(21). - C. 45-52.

2. Шаршенова А. А. Возрастные особенности адаптационных механизмов вегетативной нейрвной системы у детей среднегорья / А. А. Шаршенова, 3. Дж. Мажикова // Педиатрия. - 2005. - № 3. - С. 110 113.

3. Алієва Т. А. Вікові зміни електроенцефалограми та викликаних потенціалів у дітей / Т. А. Алієва, В. Б. Павленко // Вчені записки Таврійського національного університету ім. В. Вернадського. Серія «Біологія, хімія». - 2010. - T. 23 (62), № 3. - C. 3-14.

4. Bonnefont-Rousselota D. Melatonin: Action as antioxidant and potential applications in human disease and aging / D. Bonnefont-Rousselota, F. Collin // Toxicology. - 2010. - Vol. 278, № 1. - P. 55-67.

5. Заморський I. I. Участь пінеальної залози в механізмах негайної адаптації до гострої гіпоксії / I. І. Заморський // Буковинський медичний вісник. - Т. 10, № 4. C. $42-46$. і соціальної адаптації підлітків 3 невротичними розладами психогенного генезу [9]. У наших попередніх дослідженнях було виявлено велику кількість акцентуацій темпераменту серед метеочутливих осіб. В літературі наводяться дані про зміни кількості рецепторів до мелатоніну впродовж доби [10]. Імовірно, підвищену метеочутливість дітей і дорослих можна пояснити порушенням вироблення або рецепторної дії мелатоніну.

Висновки. Попереднє введення мелатоніну дозволяє зберегти у дорослих щурів суттєво вищу активність центрального контуру регуляції серцевого ритму за умов зниженого тиску атмосфери, ніж при ізольованому впливі гіпобаричного середовища, за значеннями індексу напруження i вегетативного показника ритму у дорослих і старих щурів $(\mathrm{p}<0,05)$. Застосування препаратів мелатоніну у терапевтичних дозах у дорослих осіб, після завершення процесу статевого дозрівання, може бути корисним для профілактики метеотропних реакцій і покращення працездатності організму за несприятливих умов III типу погоди.

6. Сопова І. Ю. Вплив мелатоніну на стан пероксидного окиснення ліпідів та системи антиоксидантного захисту в базальних ядрах мозку за поєднаної дії зміненого фотоперіоду та гострої гіпоксії / І. Ю. Сопова, І. I. Заморський // Буковинський медичний вісник. - 2009. T. 13, № 4. - C. 250-254.

7. Reiter R. J. Melatonin and cardiac pathophysiology / R. J. Reiter, D. X. Tan // Heart Metab. - 2009. - Vol. 44. - P. 31-34.

8. Batmanabane M. Effect of exogenous melatonin on the onset of puberty in female albino rats / M. Batmanabane, K..G. Ramesh // The Anatomical Record. - 1996. - Vol. 45, Issue 3. - P. 519-524.

9. Проскурина Т. Ю. Клинико-психологические особенности невротических расстройств у современных подростков / Т. Ю. Проскурина, Т. Н. Матковская, В. С. Кудь // Журнал психиатрии и медицинской психологии. - 2004. - № 4 (14). - С. 127-129.

10. Waly N. E. Circadian Pattern of Melatonin MT1 and MT2 Receptor Localization in the Rat Suprachiasmatic Nucleus / N. E. Waly // Journal of Circadian Rhythms. 2015. - Vol. 13. - P. 1-7. 